\title{
GAMBARAN KADAR HEMOGLOBIN DAN MORFOLOGI ERITROSIT ANAK PENDERITA KEJANGDEMAM DIBADAN LAYANAN UMUM DAERAH (BLUD) RUMAH SAKIT UMUM CUT MEUTIA ACEH UTARA TAHUN 2016
}

\author{
Siti Rubiah ${ }^{1}$, Mauliza $^{2}$, Harvina Sawitri $^{3}$ \\ ${ }^{1}$ Pediatrics,Faculty of Medicine, Malikussaleh University, Uteunkot, Lhokseumawe, 24352, Indonesia \\ ${ }^{2}$ Pediatrics,Faculty of Medicine, Malikussaleh University, Uteunkot, Lhokseumawe, 24352, Indonesia \\ ${ }^{3}$ Pediatrics,Faculty of Medicine, Malikussaleh University, Uteunkot, Lhokseumawe, 24352, Indonesia \\ *Corresponding Author : rubiah1395@yahoo.com
}

\begin{abstract}
Abstrak
Kejang demam merupakan kelainan neurologis yang sering dijumpai pada anak. Hal ini diduga dapat dipengaruhi oleh kadar hemoglobin. Pemeriksaan hemoglobin menentukan derajat anemia. Anemia defisiensi besi merupakan faktor resiko bangkitan kejang pada anak. Gambaran morfologi eritrosit pada anemia defisiensi besi adalah hipokrom mikrositer. Anemia menyebabkan berkurangnya kemampuan transpor oksigen ke dalam jaringan yang mengakibatkan kestabilan membran sel saraf terganggu dan dapat memicu kejang. Tujuan penelitian ini untuk mengetahui gambaran kadar hemoglobin dan morfologi eritrosit pada anak penderita kejang demam. Penelitian ini merupakan deskriptif dengan desain cross-sectional. Subjek penelitian terdiri atas 30 subjek kejang demam yang dirawat di ruang rawat inap anak Rumah Sakit Umum Daerah Cut Meutia Aceh Utara Tahun 2016. Hasil analisis univariat menunjukkan bahwa kadar hemoglobin subjek kejang demam ratarata adalah $10,13 \mathrm{~g} / \mathrm{dl}$. Morfologi eritrosit pada anak kejang demam dengan anemia didapatkan terbanyak adalah hipokrom mikrositer $17(70,8 \%)$ dari 24 subjek. Kesimpulan penelitian didapatkan rata-rata kadar hemoglobin pada subjek kejang demam adalah $10,13 \%$ dan morfologi eritrosit terbanyak pada subjek anemia adalah hipokrom mikrositer.
\end{abstract}

Kata kunci : Kejang demam; hemoglobin; anemia; morfologi eritrosit

\section{The Description of Hemoglobin Levels and Erythrocyte Morphologies of Children with Febrile seizureisat Local Public Service Agency (LPSA) of Cut Meutia Aceh Utara General Hospital 2016}

\begin{abstract}
Febrile seizureis a common neurological disorder that was found in children. It is thought to be influenced by hemoglobin levels. Hemoglobin examination determines the degree of anemia. Iron deficiency anemia is a risk factor of seizure in children. The picture of erythrocyte morphology in iron deficiency anemia is hypochromic microcytic. Anemia causes a decrease in the ability of oxygen transport into the tissues then causesthe stability of nerve cell membranes to be disrupted and can trigger seizure. The aim of this researchwas to determine the hemoglobin levels and erythrocyte morphologies in children with febrile seizure.. This was descriptive researchwith cross-sectional approach. The subjects were 30 febrile seizure children whom were hospitalizedat the inpatient room of Cut Meutia Aceh Utara General Hospital 2016. The results of univariate analysis showed that the hemoglobin level mean of children with febrile seizure was mean $10,13 \mathrm{~g} / \mathrm{dl}$. The most erythrocyte morphologies in children with febrile seizure with the less of hemoglobin levels were hypochromic microcytic 17 (70.8\%) of 24 subjects. This research was concluded that the hemoglobin levels mean in children with febrile seizure was $10,13 \%$ and the most erythrocyte morphologies in children with anemia was hypochromic microcyti.
\end{abstract}

Key Words: Febrile seizure; hemoglobin, anemia; erythrocyte morphologi

Jurnal Averrous Vol.4 No.1 2018 


\section{Pendahuluan}

Kejang demam didefinisikan sebagai bangkitan kejang yang terjadi pada kenaikan suhu tubuh (suhu rektal di atas $38^{\circ} \mathrm{C}$ ) yang disebabkan oleh suatu proses ekstrakranium (Pusponegoro, 2006).Kejang demam merupakan kelainan neurologis yang sering dijumpai pada anakdan sering menjadi penyebab rawat inap di rumah sakit secara darurat. Sekitar 2 sampai 5\% anak dibawah lima tahun pernah mengalami kejang demam. ${ }^{5}$

Insidensi dan prevalensi kejadian kejang demam di tiap-tiap negara berbeda. Insiden di Amerika Serikat dan Eropa berkisar 2 sampai 5\% anak dengan usia kurang dari 5 tahun. Angka kejadian kejang demam di Asia dilaporkan lebih tinggi dan sekitar 80-90\% dari seluruh kejang demam adalah kejang demam sederhana. Angka kejadian kejang demam di Jepang cukup tinggi yaitu berkisar 9 sampai 10\%. Insiden kejang demam di Indonesia berkisar 2 sampai 4\% pada anak umur 6 bulan sampai 5 tahun (Pusponegoro, 2006). Penelitian Yuanaet al. (2010) di RSUP dr. Kariadi, diperoleh 36 anak berusia $<5$ tahun mengalami kejang demam, laki-laki berjumlah 19 subjek (52,8\%) dan perempuan 17 $\operatorname{subjek}(47,2 \%){ }^{17,19}$

Prognosis anak dengan kejang demam tergolong baik. Pencapaian intelektual tetap normal. Banyak anak akan menderita kejang lebih lanjut, 30\% kasus kejang demam akan terjadi kembali pada penyakit demam berikutnya, dan 3 sampai $6 \%$ anak-anak yang mengalami kejang demam akan menjadi epilepsi. ${ }^{18}$

Penelitian Kumari P et al. (2012) menyatakan bahwa anemia defisiensi besi merupakan faktor resiko bangkitan kejang demam sederhana pada anak umur 6 bulan sampai 3 tahun. Anemia adalah keadaan dimana massa eritrosit dan/atau massa hemoglobin yang beredar tidak dapat memenuhi fungsinya untuk menyediakan oksigen bagi jaringan tubuh. Hampir 50\% anakanak di negara berkembang mengalami anemia.Insiden anemia pada anak di Indonesia masih sering dijumpai. Data Survei Kesehatan Rumah Tangga (SKRT) tahun 2012 menyatakan bahwa prevalensi anemia pada balita sebesar 40,5\%. Anemia defisiensi besi (ADB) merupakan anemia yang terbanyak baik di negara maju maupunnegara yang sedang berkembang (Hoffbrand, 2005).Data SKRT tahun 2007 menunjukkan prevalensi ADBpada anak balita di Indonesia sekitar 40-45\%. ${ }^{12,10,1}$

Perubahan temperatur tubuh berpengaruh terhadap nilai ambang kejang dan eksitabilitas 
neural.Kenaikan suhu tubuh berpengaruh pada kanal ion dan metabolisme seluler serta produksi Adenosine Triphosphate (ATP). Setiap kenaikan suhu tubuh $1^{0} \mathrm{C}$ akan meningkatkan metabolisme basal 10\%-15\% dan kebutuhan oksigen 20\%. Akibat keadaan tersebut, reaksi oksidasi berlangsung lebih cepat sehingga oksigen lebih cepat habis. Oksigen dalam jaringan yang kurang dapat menyebabkan terjadi keadaan hipoksia.Anemia yang ditunjukkan dengan kadar hemoglobin yang rendah menyebabkan kemampuan sel darah merah pengikat oksigen menurun . $^{2,7}$

Oksigen dibutuhkan dalam proses transport aktif ion Na-K yang berguna untuk menstabilkan membran sel saraf. Kestabilan membran sel saraf yang terganggu dapat mengakibatkan konsentrasi ion $\mathrm{Na}$ intrasel meningkat sehingga terjadi depolarisasi. Kejang terjadi apabila terdapat depolarisasi berlebihan pada neuron dalam sistem saraf pusat dan jika kondisi ini berada pada level yang tetap dan mendapat rangsangan yang kuat seperti demam tinggi $\left(>38^{0}\right.$ C) dan kondisi anemia . ${ }^{12,3}$

Tujuan penelitian ini adalah untuk mengetahui gambaran kadar hemoglobin dan morfologi eritrosit pada anak penderita kejang demam di Badan Layanan Umum Daerah (BLUD) Rumah Sakit Umum Cut Meutia Aceh Utara Tahun 2016.

\section{Metode}

Jenis penelitian ini bersifat deskriptif dengan desain cross sectional. Penelitian diukur atau dikumpulakan dalam waktu yang bersamaan. Penelitian ini dilaksanakan di Badan Layanan Umum Daerah Rumah Sakit Umum Cut Meutia Kabupaten Aceh Utara mulai bulan Februari sampai Mei 2017. Populasi terjangkau penelitian ini adalah seluruh balita penderita kejang demam yang menjalani rawat inap di ruang anak BLUD Rumah Sakit Umum Cut Meutia tahun 2016. Sampel dalam penelitian ini adalah seluruh populasi yang telah memenuhi kriteria inklusi dan eksklusi. Kriteria inklusinya adalah anak usia 6 bulan sampai 5 tahun, anak dengan kejang demam simplek dan komplek dan anak yang menjalani rawat inap. Sementara kriteria eksklusi dalam penelitian ini adalah anak dengan penyakit kronis, anak yang memerlukan transfusi darah, anak dengan perdarahan, data rekam medis tidak lengkap. Sampel diambil dengan menggunakan teknik consecutive sampling.

Instrumen yang digunakan dalam penelitian ini adalah rekam medik pasien kejang demam pada anak yang menjalani rawat inap di BLUD RSU Cut Meutia Kabupaten Aceh Utara tahun 
2016. Yaitu data mengenai karakteristik, gambaran kadar hemoglobin dan morfologi eritrosit pada anak penderita kejang demam di Badan LayananUmum Daerah (BLUD) Rumah Sakit Umum Cut Meutia Aceh Utara tahun 2016

\section{Hasil Penelitian}

Tabel 1. Distribusi frekuensi karakteristik subjek penelitian

\begin{tabular}{ccc}
\hline Karakteristik & $\mathbf{N}$ & $\mathbf{( \% )}$ \\
\hline Jenis kelamin & 17 & 56,7 \\
Laki-laki & 13 & 43,3 \\
Perempuan & & \\
Usia (bulan) & 7 & 23,3 \\
$<12$ & 11 & 36,7 \\
$12-23$ & 6 & 20,0 \\
$24-35$ & 2 & 6,7 \\
$36-47$ & 4 & 13,3 \\
$48-60$ & & \\
& & \\
\hline
\end{tabular}

Sumber: Data sekunder, 2016

Tabel 1 dari 30 sampel menunjukkan bahwa sebagian besar responden yang mengalami kejang demam adalah laki-lakiyaitu sebanyak 17 anak (56,7\%). Sebagian besar usia anak yang mengalami kejang demam terjadi pada rentang usia 12-23 bulan yaitu sebesar 11 anak (36,7\%).

Tabel 2. Distribusi frekuensi klasifikasi kejang demam

\begin{tabular}{ccc}
\hline Kejang demam & N & (\%) \\
\hline Simpleks & 19 & 63,3 \\
Kompleks & 11 & 36,7 \\
\hline Total & 30 & 100
\end{tabular}

Sumber: Data sekunder, 2016 
Dari Tabel 2. menunjukkan bahwa kejang demam simpleks didapatkan lebih banyak pada anak kejang demam yaitu sebanyak 19 anak(63,3\%) sedangkan kejang demam kompleks yaitu sebanyak 11 anak $(36,7 \%)$.

Tabel 3. Gambaran kadar hemoglobin

\begin{tabular}{cccccc}
\hline & n & Median & Minimal & Maksimal & Rerata \pm SB \\
\hline $\begin{array}{c}\text { Kadar } \\
\text { hemoglobin(g/dl) }\end{array}$ & 30 & 10,0 & 8,8 & 12,6 & $10,13 \pm 0,9363$ \\
\hline
\end{tabular}

Sumber: Data sekunder, 2016

Dari Tabel 3 menunjukkan bahwa kadar hemoglobin subjek penelitian paling tinggi adalah (12,6 g/dl), sedangkan kadar hemoglobin paling rendah adalah $(8,8 \mathrm{~g} / \mathrm{dl})$. Rata-rata kadar hemoglobin pada subjek penelitian ini adalah $(10,13 \mathrm{~g} / \mathrm{dl})$.

Tabel 4. Gambaran kadar hemoglobin anak kejang demam simpleks dan kompleks

\begin{tabular}{cccccc}
\hline $\begin{array}{c}\text { Kadar hemoglobin } \\
(\mathbf{g} / \mathbf{d l})\end{array}$ & $\mathbf{n}$ & Median & Minimal & Maksimal & Rerata \pm SB \\
\hline Simpleks & 19 & 10,1 & 9,0 & 11,7 & $10,184 \pm 0,8355$ \\
\hline Kompleks & 11 & 9,80 & 8,8 & 12,6 & $10.027 \pm 1,1881$
\end{tabular}

Sumber: Data sekunder, 2016

Tabel 4 menunjukkan bahwa rata-rata kadar hemoglobin pada anak kejang demam kompleks sedikit lebih rendah yaitu 10,027g/dl, daripada kadar hemoglobin pada anak kejang demam simpleks yaitu $10,184 \mathrm{~g} / \mathrm{dl}$. 
Tabel Grafik 5. Distribusi frekuensi kadar hemoglobin berdasarkan kategori anemia dan tidak anemia

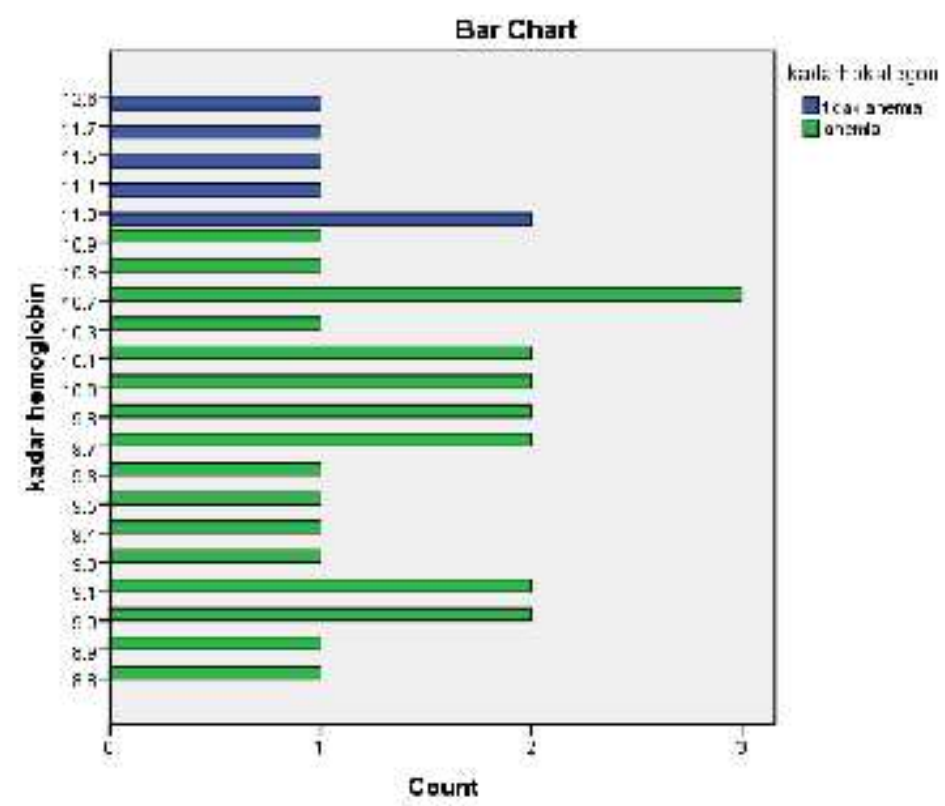

Sumber: Data sekunder, 2016

Tabel grafik 5 menunjukkan bahwa kadar hemoglobin yang tergolong anemia pada anak kejang demam didapatkan lebih banyak yaitu sebanyak 24 anak (80\%), daripada anak yang tidak mengalami anemia yaitu sebanyak 6 anak (20\%).

Tabel 6. Distribusi frekuensi morfologi eritrosit

\begin{tabular}{ccc}
\hline Morfologi eritrosit & N & $(\%)$ \\
\hline Hipokrom mikrositer & 17 & 56,7 \\
Normokrom normositer & 13 & 43,3 \\
Makrositer & 0 & 0 \\
\hline Total & 30 & 100
\end{tabular}

Sumber: Data sekunder, 2016

Tabel 6 menunjukkan bahwa morfologi eritrosit hipokrom mikrositer pada anak kejang demam didapatkan lebih banyak yaitu sebanyak 17 anak (56,7\%), morfologi eritrosit normokrom normositer didapatkan sebanyak 13 anak (43,3\%), sedangkan morfologi eritrosit makrositer tidak ditemukan. 
Tabel 7. Distribusi frekuensi morfologi eritrosit dengan kadar Hb berdasarkan kategori anemia dan tidak anemia pada anak kejang demam di Rumah Sakit Umum Cut Meutia Aceh Utara tahun 2016.

Morfologi eritrosit

Total

\begin{tabular}{llccccc} 
& & & $\begin{array}{c}\text { Hipokrom } \\
\text { mikrositer }\end{array}$ & $\begin{array}{c}\text { Normokrom } \\
\text { normositer }\end{array}$ & Makrositer & \\
\hline $\begin{array}{l}\text { Kadar } \\
\text { Hb }\end{array}$ & $\begin{array}{l}\text { Tidak } \\
\text { anemia }\end{array}$ & $\mathrm{n}$ & 0 & 6 & 0 & 6 \\
& $(\%)$ & 0 & 100 & 0 & 100 \\
\cline { 2 - 7 } & Anemia & $\mathrm{n}$ & 17 & 7 & 0 & 24 \\
& & $(\%)$ & 70,8 & 29,2 & 0 & 100 \\
\hline Total & & $\mathrm{n}$ & 17 & 13 & 0 & 30 \\
& & $(\%)$ & 56.7 & 43.3 & 0 & 100
\end{tabular}

Sumber: Data Sekunder, 2016

Tabel 7 menunjukkan bahwa morfologi eritrosit hipokrom mikrositer pada kadar hemoglobin yang tergolong anemia didapatkan lebih banyak yaitu 17 anak(70,8\%) dibandingkan morfologi eritrosit normokrom normositer sebanyak 7 anak(29,2\%).

Tabel 8. Distribusi frekuensi morfologi eritrosit pada anak kejang simpleks dan kompleks di Rumah Sakit Umum Cut Meutia Aceh Utara tahun 2016.

Morfologi eritrosit

Total

Hipokrom Normokrom Makrositer

mikrositer normositer

\begin{tabular}{lcccccc}
\hline $\begin{array}{l}\text { Kejang } \\
\text { demam }\end{array}$ & Simpleks & $\mathrm{n}$ & 12 & 7 & 0 & 19 \\
& $(\%)$ & 63.2 & 36.8 & 0 & 100 \\
\cline { 2 - 6 } & Kompleks & $\mathrm{n}$ & 5 & 6 & 0 & 11 \\
& $(\%)$ & 45.5 & 54.5 & 0 & 0 \\
\hline Total & $\mathrm{n}$ & 17 & 13 & 0 & 100 \\
& $(\%)$ & 56.7 & 43.3 & 0 & \\
\hline
\end{tabular}

Sumber: Data Sekunder, 2016

Tabel 8 menunjukkan bahwa morfologi eritrosit hipokrom mikrositer banyak dijumpai pada anak kejang demam simpleks yaitu sebesar 12 anak $(63,2 \%)$. 
Tabel 8. Distribusi frekuensi kadar Hb kategori, pada anak kejang demam simpleks dan kompleks di Rumah Sakit Umum Cut Meutia Aceh Utara tahun 2016.

\begin{tabular}{|c|c|c|c|c|c|}
\hline & & & \multicolumn{2}{|c|}{ Kadar Hb kategori } & \multirow[t]{2}{*}{ Total } \\
\hline & & & Tidak anemia & anemia & \\
\hline \multirow{6}{*}{$\begin{array}{l}\text { Kejang } \\
\text { demam }\end{array}$} & Simpleks & $\mathrm{n}$ & 4 & 15 & 19 \\
\hline & & $(\%)$ & 21.1 & 78.9 & 100 \\
\hline & Kompleks & $\mathrm{n}$ & 2 & 9 & 11 \\
\hline & & $(\%)$ & 18.2 & 81.8 & 100 \\
\hline & \multirow[t]{2}{*}{ Total } & $\mathrm{n}$ & 6 & 24 & 30 \\
\hline & & $(\%)$ & 20 & 80 & 100 \\
\hline
\end{tabular}

Sumber: Data sekunder, 2016

Tabel 9 menunjukkan bahwa anak dengan kejang demam simpleks mengalami anemia yaitu sebanyak 15 anak (78,9\%), sedangkan anak dengan kejang demam kompleks mengalami anemia sebanyak 9 anak $(81,8 \%)$.

\section{Pembahasan}

Hasil penelitian inidari 30 anak kejang demam didapatkan bahwa sebagian besar responden yang mengalami kejang demam adalah anak laki-laki yaitu sebanyak 17 anak (56,7\%). Penelitian ini sesuai dengan penelitian Rani et al. (2011) mengenai karakteristik penderita kejang demam pada balita Rawat Inap di RSUD Dr. Pirngadi Medan didapatkan bahwa anak laki-laki sedikit lebih sering mengalami kejang demamy aitu 57,3\% dari pada anak perempuan 42,7\%. Hal ini disebabkan karena maturasi serebral pada anak perempuan lebih cepat daripada anaklaki-laki. ${ }^{14,15}$

Hasil penelitian ini didapatkan bahwa Sebagian besar usia anak yang mengalami kejang demam terjadi pada rentangusia 12-23 bulan yaitu sebesar 11 orang (36,7\%). Penelitian ini sesuai dengan penelitian Fuadiet al. (2010) menyatakan bahwa usia $<2$ tahun saat pertama kali kejang merupakan factor resiko terjadinya kejang demam secara bermakna, dimana usia $<2$ tahun memiliki resiko 3,4 kali lipat menderita kejang demam. Hal inidisebabkan karena usia $<2$ tahun merupakan masa developmental window (masa perkembangan otak fase organisasi). Pada masa developmental window keadaan otak belum matang, pada keadaan otak yang belum matang reseptor untuk asam glutamate baik ionotropik maupun metabotropik sebagai reseptor eksitator padat dan aktif, sebaliknya reseptor GABA sebagai inhibitor kurang aktif, sehingga otak belum matang eksitasi lebih dominan disbanding inhibisi. 
Corticotropin Releasing Hormon (CRH) merupakan neuropeptide ksitator, berpotensi sebagai prokovulsan. Keadaan otak yang belum matang, kadar CRH di hipokampus tinggi, berpotensi untuk terjadi bangkitan kejang apabila terpicu oleh demam. Mekanisme homeostasis pada otak belum matang masih lemah, akan berubah sejalan dengan perkembangan otak dan pertambahan umur, oleh Karena pada keadaan otak belum matang neural $\mathrm{Na}^{+} / \mathrm{K}^{+}$ATPase masih kurang. Pada otak yang belum matang regulasi ion $\mathrm{Na}^{+}, \mathrm{K}^{+}$, dan $\mathrm{Ca}^{++}$belum sempurna, sehingga mengakibatkan gangguan repolarisasi pasca depolarisasi dan meningkatkan eksitabilitas neuron. ${ }^{6}$

Keadaan otak yang belum matang mempunyai eksitabilitas neural lebih tinggi dibandingkan otak yang sudah matang. Masa ini disebut sebagai developmental window dan rentan terhadap bangkitan kejang, eksitator lebih dominan dibanding inhibitor, sehingga tidak ada keseimbangan antara eksitator dan inhibitor. Anak yang mendapat serangan bangkitan kejang demam pada umur awa lmasa developmental window mempunyai waktul ebih lama mengalami fase eksitabilitas neural dibandingkan anak yang mendapat serangan kejang demam pada umur akhir masa developmental window. Apabila anak mengalami stimulus berupa demam pada otak fase eksitabilitas akan mudah terjadi bangkitan kejang. ${ }^{6}$

Penelitian ini menunjukkan bahwa persentase kejadian kejang demam simpleks lebih besar yaitu sebanyak (63,3\%), dibandingkan kejadian kejang demam kompleks (36,7\%). Hal tersebut sesuai dengan pendapat beberapa ahli yang menyatakan bahwa sebagian besar kejang demam berupa kejang demam sederhana (63\%), sedangkan kejadian kejang demam kompleks lebih sedikit (35\%). Hal ini berdasarkan pada penentuan kasus kejang yaitu berupa sifat kejang (umum atau fokal), lamanya kejang, dan frekuensi kejang (berulang dalam 24 jam atau tidak). Kejang demam simpleks jika kejang berlangsung kurang dari 15 menit, kejang bersifat umum, dan tidak berulang dalam 24 jam. Kejang demam kompleks jika kejang bersifat fokal atau parsial, berlangsung lebih dari 15 menit dan berulang dalam 24 jam. ${ }^{13,9}$

Nilai rata-rata kadar hemoglobin pada penelitian ini didapatkan 10,13 g/dl yang termasuk kedalam kategori anemia sangat ringan. Penelitian ini sesuai dengan penelitian yang dilakukan oleh Dasmayanti et al. (2015) mengenai hubungan kadar hemoglobin dengan kejang demam pada anak balita, yang melaporkan kadar hemoglobin ( $\mathrm{Hb}$ ) pada subjek kejang demam didapatkan termasuk kedalam kategori anemia sangat ringan. Hasil penelitian kadar hemoglobin berdasarkan kategori anemia dan tidak anemia pada penelitian ini didapatkan subjek yang termasuk kategori anemia lebih banyak yaitu berjumlah 24 anak (80\%) daripada anak yang tidak mengalami anemia yaitu berjumlah 6 anak (20\%). Hal inidisebabkan karena pada kondisi anemia yang ditunjukkan dengan kadar hemoglobin yang rendah menyebabkan kemampuan sel darah merah pengikat oksigen menurun. ${ }^{7}$ 
Oksigen diperlukan dalam semua proses metabolism zat gizi dalam tubuh untuk menghasilkan energi. Oksigen juga sangat penting bagi perkembangan dan aktivitas selotak.Tanpa suplai oksigen yang cukup, sel otak tidak dapat berkembang dan beraktivitas secara optimal. Oksigen dibutuhkan dalam proses transport aktif ion Na-K yang berguna untuk menstabilkan membran sel saraf. Kestabilan membran sel saraf yang terganggu dapat mengakibatkan konsentrasi ion $\mathrm{Na}$ intrasel meningkat sehingga terjadi depolarisasi. Kejang terjadi apabila terdapat depolarisasi berlebihan pada neuron dalam sistem saraf pusat dan jika kondisi ini berada pada level yang tetap dan mendapat rangsangan yang kuat seperti demam tinggi $\left(>38^{\circ} \mathrm{C}\right)$ dan kondisi anemia. ${ }^{8,3}$

Penelitian ini juga didapatkan rata-rata kadar hemoglobin pada anak kejang demam kompleks sedikit lebih rendah yaitu 10,027g/dl, sedangkan kadar rata-rata hemoglobin pada kejang demam simpleks yaitu10,184 g/dl. Hal ini juga terkait dengan insidensi kejang demam simpleks yang lebih tinggi. Kejang demam simpleks dan kompleks dapat dibedakan berdasarkan pada manifestasi klinis yang ditimbulkan. Kejang demam simpleks berlangsung kurang dari 15 menit, kejang bersifat umum, dan tidak berulang dalam 24 jam, sedangkan kejang demam kompleks bersifat fokal atau parsial, berlangsung lebih dari 15 menit dan berulang dalam 24 jam. Dengan kata lain bahwa anemia pada pasien kejang demam dapat memperberat manifestasi yang akan timbul (Helmi H, 2014). Penelitian yang dilakukan oleh Khanis (2010) menyatakan bahwa anak dengan anemia mempunyai resiko untuk menderita kejang demam 10,8 kali lebih besar dibandingkan anak yang tidak anemia. ${ }^{11}$

Variabel morfologi eritrosit pada penelitian ini didapatkan anemia terbanyak pada anak kejang demam yaitu hipokrom mikrositer yaitu sebanyak 17 anak (70,8\%), sedangkan anemia normokrom normositer sebanyak 7 anak (29,2\%). Anemia hipokrommikrositer dapat disebabkan salah satunya akibat defisiensi zat besi. Anemia defisiensi besi merupakan anemia paling banyak ditemukan di Indonesia. Hasil Survei Kesehatan Rumah Tangga (SKRT) tahun 2007 menunjukkan prevalensi anemia defisiensi besi di Indonesia pada anak balita adalah 40-45\%. Defisiensi besi pada anak sebagian besar disebabkan oleh factor nutrisi. Defisiensi besi pada usia balita terjadi karena: suplai besi yang tidak adekuat (penurunan masukan besi dan/atau rendahnya ketersediaan besi dalam makanan, meningkatnya kebutuhan besi karena proses tumbuh kembang dan meningkatnya kehilangan besi (akibat diare, perdarahan gastrointestinal). ${ }^{4}$

Apabila anemia ini disebabkan defisiensi besi, kandungan besi dalam otak akan berkurang. Besi merupakan komponen esensial pada pertumbuhan otak dan fungsi system saraf pusat. Pertumbuhan otak sangat sensitive terhadap perubahan status besi, karena pertumbuhan dan perkembangan otak yang cepat serta terjadi pada jeda waktu yang singkat sehingga defisiensi besi dapat mengakibatkan gangguan fungsi otak. Besi juga sangat esensial dalam proses mielinisasi, metabolisme neuron, dan proses di neurotransmitter. Defisiensi besi dapat menyebabkan enzim untuk sintesis GABA yaitu 
Glutamic Acid Dearboylase (GAD) berkurang secara signifikan dan meningkatkan kadar asamglutamat di otak. Ketidakseimbangan antara neurotransmitter eksitator asam glutamate dan inhibitor gamma aminobutyric acid (GABA) berperan penting dalam menimbulkan kejang demam. ${ }^{3}$

Morfologi eritrosit hipokrom mikrositer lebih banyak di temukan pada anak kejang demam sederhana yaitu sebanyak 12 anak (63,2\%). Hal ini bias saja terjadi terkait insidensi kejang demam simpleks didapatkan lebih banyak disbandingkan dengan kejang demam kompleks. Penelitian Kumari P et al. (2012) menyatakan bahwa anemia defisiensi besi merupakan faktor resiko bangkitan kejang demam sederhana pada anak umur 6 bulan sampai 3 tahun. Penelitian lainnya yang dilakukan oleh Srinivasa $S$ dan Sai Praneeth Reddy (2014) menyatakan bahwa anak dengan kejang demam hampir dua kali lebih mungkin mengalami anemia defisiensi besi dibandingkan dengan anak demam tanpa kejang. Anemia zat besi dapat dianggap sebagai factor risiko yang dapat dimodifikasi yang menjadi predisposisi untuk kejang demam pada anak antara usia 6 bulan sampai 5 tahun. Keterbatasan pada penelitian ini, peneliti hanya menilai morfologi eritrosit subjek penelitian tanpa menilai pemeriksaan profil besi secaras pesifik, disebabkan karena rumah sakit tempat peneliti melakukan penelitian tidak memiliki pemeriksaan profil besi. ${ }^{12,16}$

Pada penelitian ini didapatkan gambaran kadar hemoglobin pada anak penderita kejang demam di Badan LayananUmum Daerah (BLUD) Rumah Sakit Umum Cut Meutia Aceh Utara tahun 2016, ratarata adalah 10,13 g/dl. Gambaran rata-rata kadar hemoglobin pada anak kejang demam kompleks didapatkan sedikit lebih rendah yaitu10,027 g/dl, daripada kadar hemoglobin pada anak kejang demam simpleks yaitu 10,184 g/dl. Gambaran morfologi eritrosit pada anak penderita kejang demam di Badan Layanan Umum Daerah (BLUD) Rumah Sakit Umum Cut Meutia Aceh Utara tahun 2016 terbanyak adalah hipokrom mikrositer. Gambaran morfologi eritrosit hipokrom mikrositer didapatkan lebih banyak pada anak kejang demam simpleks yaitu sebanyak 12 anak (63,2\%).

Saran dari penelitian ini adalah Bagi institusi kesehatan diharapkan dapat melakukan promosi kesehatan mengenai kejang demam dan anemia pada anak serta melakukan edukasi kepada orang tua mengenai pemberian nutrisi yang adekuat khususnya kecukupan zat besi pada makanan. Diharapkan bagi institusi pendidikan bahwa penelitian ini dapat dijadikan bahan untuk penelitian selanjutnya dengan metode penelitian yang berbeda dan dengan sampel yang lebih banyak, dengan tempat penelitian yang lebih luas dan factor risiko lain dan pemeriksaan yang lebih spefisik lagi.

\section{Daftar Pustaka}

1. Bakta, I Made., 2007. HematologiKlinisRingkasan. EGC, Jakarta,p:11-17

2. Bahtera, T., 2007. Faktor risiko kejang demam berulang sebagai prediktor bangkitan kejang demam berulang. Kajian mutasi gen pintu voltase kanal ion natrium [Disertasi]. Semarang: Departemen Ilmu Kesehatan Anak Universitas Diponegoro.

3. Beard J, 2007. Iron deficiency alters brain development and functioning. J Nutr; 133:146 
4. Dwiprahasto I. Terapi anemia defisiensi besi berbasis bukti.Dalam : Rina Triasih, ed. Anemia defisiensi besi. Bagian Ilmu Kesehatan Anak FK UGM; 2007.p.68-82.

5. Friedman, Marla J., Ghazala Q.,Sharieff, 2006. Seizures in Children.Pediatric Clinics of North America. 53: 257- 277

6. Fuadiet al., 2010.FaktorRisikoKejangDemampadaAnak.Sari Pediatri, 12 (3):142-149

7. Georgieff, 2007. Nutrition and the developing brain: nutrient priorities and measurement. $\mathrm{Am} J$ Clin Nutr;85:614-20.

8. Hartfield, D.S.,et al., 2009. The association between iron deficiency and febrile seizures in childhood. Clin Pediatr;20:1-7.

9. Jonhston, M.V., 2007. Seizure in childhood and prevalence of febrile seizure. In : Behrman RE, Kliegman RM, Jenson HB, ed. Nelson Textbook of Pediatrics. 18th ed. Philadelphia : WB Saunders Co;p.2457-71

10. Kemenkes RI., 2014. Profil Kesehatan Indonesia Tahun2013. Jakarta: Kemenkes RI

11. Khanis, A., 2010.Defisiensi besi dengan parameter sTfR sebagai faktor risiko bangkitan kejang demam [Tesis]. Semarang: Departemen Ilmu Kesehatan Anak Universitas Diponegoro

12. Kumari, P.,et al., 2012. Iron deficincy as a Risk factor for simple febrile seizures - a case control study. Indian pediatr. 2012;49:17-9

13. Lumbantobing, S.M., 2004. Kejang Demam. Jakarta: Balai Penerbit FKUI.

14. Rani, S., et al, 2011. Karakteristik Penderita Kejang Demam Pada Balita Rawat Inap di RSUD Dr. Pirngadi Medan Tahun 2010-2011.Departemen Epidemiologi FKM USU

15. Rogol, A.D., Roemmich, J.N, Clark, P.A., 2006. Growth at Puberty. Elsevier Science. 31(6):192-200.

16. Srinivasa S dan Sai P.R., 2014. Iron deficiency anemia in children with simple febrile seizureA cohort study. Curr pediatr Res;18(2);95-98

17. Stafstrom, C.E., 2007. The incidence and prevalence of febrile seizure. Dalam: Baram TZ, Shinnar S, penyunting. Febrile Seizure. San Diego: Academic press. P 1-25

18. Schwartz, M.William.,2005. PedomanKlinisPediatri. Jakarta: EGC

19. Yuana, I., Bahtera, T., Wijayahadi, N., 2010. Korelasi kadar seng serum dan bangkitan kejang demam. Sari Pediatri ;12:150-6. 